\title{
Variability in the Macrozooplankton Community off the Antarctic Peninsula
}

\author{
V. Siegel ${ }^{1}$ and U. Piatkowski ${ }^{2}$ \\ ${ }^{1}$ Institut für Seefischerei, Bundesforschungsanstalt für Fischerei, Palmaille 9, D-2000 Hamburg 50, Federal Republic of Germany \\ ${ }^{2}$ Institut für Meereskunde an der Universität Kiel, Düsternbrooker Weg 20, D-2300 Kiel 1, Federal Republic of Germany
}

Received 3 March 1989; accepted 2 November 1989

Summary. This paper presents an analysis of zooplankton net sampling surveys carried out during four expeditions to the Antarctic Peninsula region. Cluster analysis documented two to three site groupings for the epipelagic zone and one mesopelagic site cluster below 200 to $300 \mathrm{~m}$ depth. Analysis of species dominance, constancy, diversity and evenness indices did not allow clear designation and separation of communities in terms of these parameters.

Computation of a rank correlation matrix for each season allowed the characterization of species groups. There were no perfect indicator species in the very strict sense. The main differences in the composition of the zooplankton between the site clusters were due mainly to changes in abundance rather than to presence or absence of particular species. However, the interpretation of the complex species and site groupings led to the conclusion that we can define three distinct communities: an oceanic, a neritic, and a mesopelagic community beneath 200 to $300 \mathrm{~m}$. A so-called transitional cluster represents a mixing zone created by frequent occurrence of species from both the oceanic and neritic community. The location of the described oceanic and neritic community sites seem to be relatively stable with minor latitudinal changes during the seasons, while occurrence and abundance of most species changes with the time of the year. The usefulness of particular species (e.g. Euphausia superba) as indicator species also change during the year

\section{Introduction}

The composition of the Southern Ocean zooplankton was first analysed by Mackintosh (1934) for the Atlantic sector and Hardy and Gunther (1935) for the South Georgia region. Mackintosh (1934) concentrated on the relative abundance of many species and described the preference of common species for cold or warmer waters using this as a basis for the identification of regions. The Graham Land area was characterized by thin plankton abundance and cold-water species, while a northern zone in the vicinity of the Antarctic Convergence had a uniform and stable plankton comprised of warm-water species. The boundaries of this region were indistinct with many widespread species so Mackintosh (1934) mapped a broad transitional belt between the regions.

Much of the subsequent work in this area has concentrated on single species or groups (David 1958; Marr 1962; Foxton 1966; Kane 1966). Recently, however, the need to advance the work of Mackintosh (1934) analysing the composition of the plankton community of Antarctic waters has been recognised (Nemoto and Harrison 1981; Hempel 1985). The waters of the Antarctic Peninsula region are of particular interest. This is a region of complex hydrographic conditions where dense spawning aggregations of krill Euphausia superba occur.

Several authors have analysed the zooplankton composition in this region (Jazdzewski et al. 1982; Hopkins 1985; Witek et al. 1985; Montu and Oliveira 1986; Piatkowski 1989) basing their investigations on a short period of the austral summer season. A more comprehensive investigation, however, which also emphasizes seasonal variability in this region, is still required.

It is clear from the historical discussions that a variety of complex ecological assemblages exist in the Antarctic zooplankton. We refer to the definition suggested by Mills (1969): community means a group of organisms occurring in a particular environment, presumably interacting with each other and with the environment, and separable by means of ecological surveys from other groups. By comparing the zooplankton composition of net samples of four expeditions to the Antarctic Peninsula during different seasons the present paper analyses the associations of station groups as well as species aggregations and their seasonal variations. We will supply a relevant contribution to the varying constancy of the associations in order to improve our knowledge of the components within and between the different associations.

\section{Material and Methods}

Zooplankton was sampled during four Antarctic expeditions by the research vessels John Biscoe (February 1982) Walther Herwig (March 


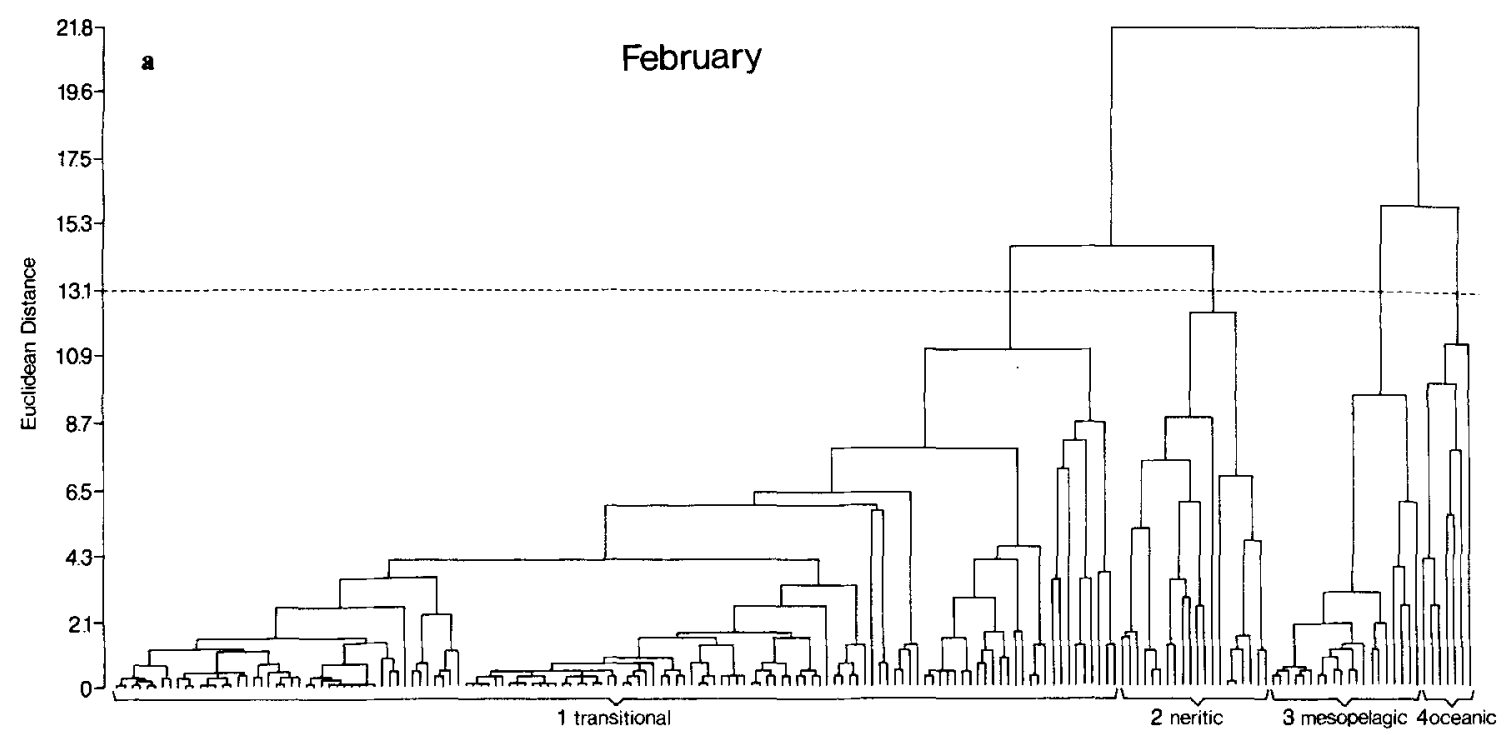

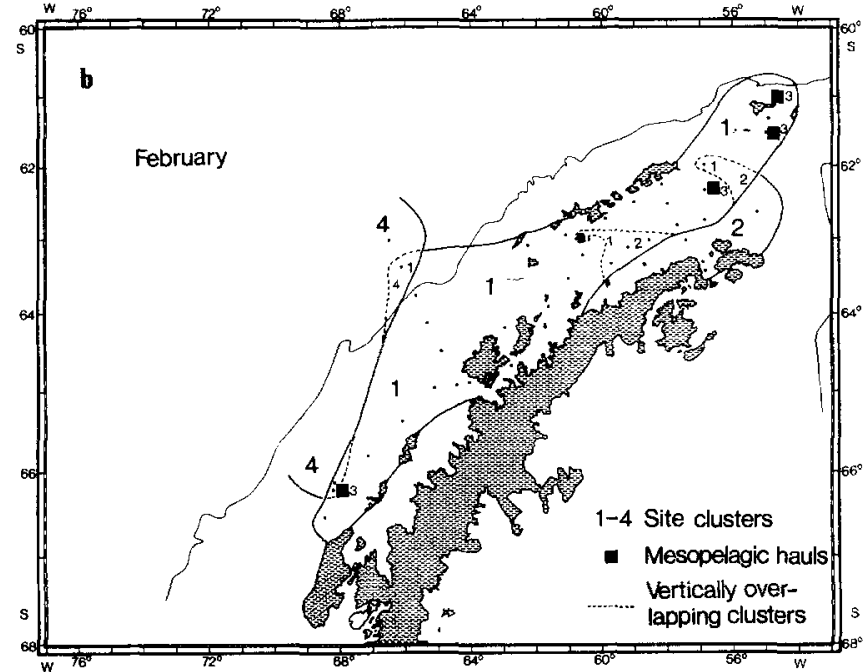

Fig. 1. a Dendrogram derived from cluster analysis (with stations as individuals) for species abundance data from February 1982 (dashed line indicates the chosen similarity level for station grouping). b Geographical distribution of station clusters off the Antarctic Peninsula in February (dashed lines indicate the vertically overlapping clusters, figures refer to cluster numbers of the dendrogram) to $750 \mathrm{~m}$. Towing speed was about 2.5 knots. Filtered water volumes were calculated, considering net speed, net angle, and flow data (Pommeranz et al. 1982). Only samples from RMT 8 catches (mesh size $4.5 \mathrm{~mm}$ ) were analysed for the present study.

Immediately after each haul samples were stored in $4 \%$ buffered formalin seawater solution. Sorting and counting of taxa followed some days later on board the ship. Taxa were identified to the species level as far as possible. Copepods were excluded from the macrozooplankton analysis, because results of Hubold et al. (1988) showed that in the size fraction $>500 \mu \mathrm{m}$ copepods were not represented adequately. Adult fish (Myctophidae and Pleuragramma antarcticum) were excluded from the data, because their abundances are strongly affected by net avoidance.

Statistical analysis of species data was carried out using the SPSS, CSS and CLUSTAN statistical packages. Standardised abundances $\left(n / 1000 \mathrm{~m}^{3}\right)$ were submitted to an agglomerative hierarchical procedure using the Euclidean distance and Ward's method of grouping the data. Because occasional very high abundance values of single species (e.g. Euphausia superba, Salpa thompsoni, Thysanoessa macrura) bias the mean abundance we used transformed $\ln (n+1)$ data to reduce the weighting of very abundant species. The rank correlation analysis by species was run with standardised values to $1000 \mathrm{~m}^{3}$ to obtain Spearman's correlation coefficients (Snedecor and Cochran 1980). Those species which occurred only as a single specimen at a single station in one cluster were excluded from the matrix. Reduction was necessary because random cooccurrence of two very rare species can result in a correlation as having identical distribution.
1985) and Polarstern (May/June 1986, November 1987). Details on general scientific objectives of the cruises, station lists and cruise tracks are summarized by Hempel and Heywood (1982), Piatkowski (1983), Anonymous (1986), Schnack-Schiel (1987) and Fütterer (1988).

The survey area was located along the Antarctic Peninsula $\left(54^{\circ} \mathrm{W}\right.$ to $\left.72^{\circ} \mathrm{W}\right)$ between Elephant Island $\left(60^{\circ} \mathrm{S}\right)$ and Adelaide Island $\left(68^{\circ} \mathrm{S}\right)$. The station grid was based on modified SIBEX transects (except for February 1982), covering the shelf areas and extending into oceanic waters. Due to the inaccessability of parts of the area caused by heavy pack-ice conditions the number of stations varied from season to season.

The standard gear used during all surveys was the Rectangular Midwater Trawl (RMT 1+8) (Baker et al. 1973). Standard oblique tows were carried out from $200 \mathrm{~m}$ depth to the surface, at shallower stations the net was opened $10 \mathrm{~m}$ above the bottom. In 1982 three depth strata in the upper $200 \mathrm{~m}$ water column of each station were sampled by the multiple opening and closing RMT (Roe and Shale 1979). Additional opening and closing hauls were carried out in various depth layers down

\section{Results}

\section{Site Clusters of Stations}

In the first analysis 180 of the samples collected during February 1982 were used. These covered the depth range from 0 to $750 \mathrm{~m}$. The sample affinities are plotted as a dendrogram (Fig. 1a) based on the logarithmic transformed abundances of species encountered. At an arbitrary similarity level of $40 \%$ four major net haul clusters emerge describing station groups of similar geographical origin. Cluster 1 represents hauls from the Peninsula shelf area (Fig. 1b). 20 hauls from neritic areas of the Bransfied Strait and the Deception Island lagoon were grouped within cluster 2 and were restricted to the upper $200 \mathrm{~m}$ depth stratum. Where cluster 1 and 2 overlap, the neritic 

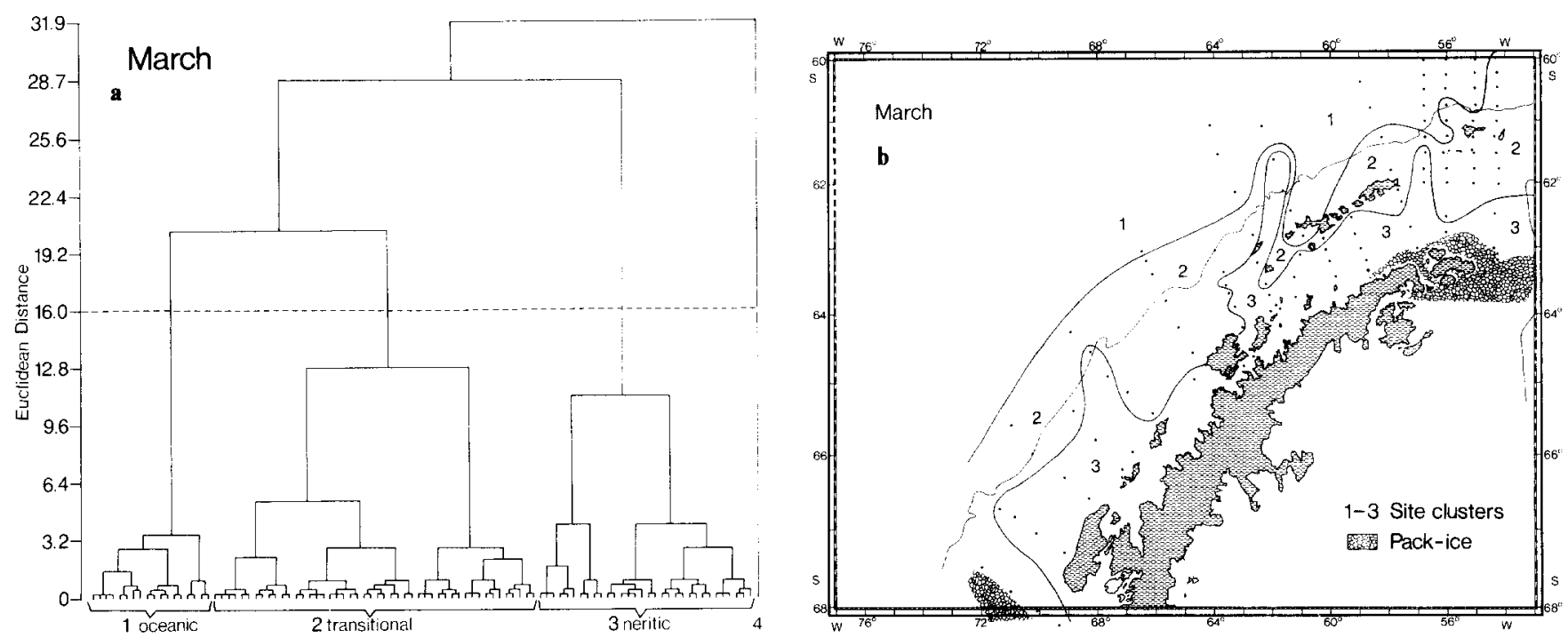

Fig. 2. a Dendrogram for site clusters from species abunaance data of March 1985. b Geographical distribution of site clusters in March 1985
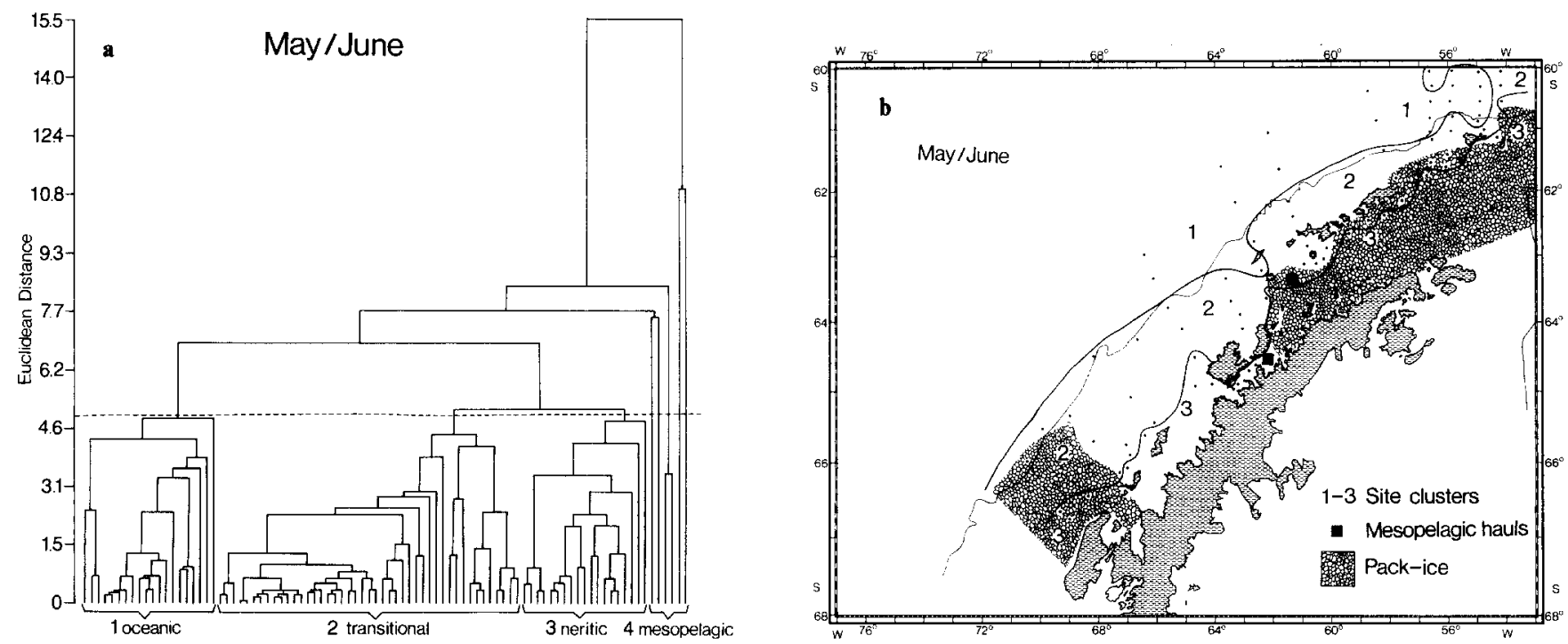

Fig. 3. a Dendrogram for site clusters from species abundance data of May/June winter cruise 1986. b Geographical distribution of site clusters in May/June 1986

cluster is superimposed on the so-called transitional cluster. From 20 hauls grouped in cluster 3 only three were carried out in the 0 to $200 \mathrm{~m}$ layer, 17 hauls were located in the mesopelagic 200 to $750 \mathrm{~m}$ strata north and south of Elephant Island, in the eastern Bransfield Strait and in the northern Bellingshausen Sea. Only one deep haul extending beyond $200 \mathrm{~m}$ depth belonged to cluster 4 which characterized mainly oceanic waters.

Setting a similarity level for dendrograms is in general somewhat arbitrary, we consider it more important to adjust the similarity level to obviously meaningful groupings rather than to force the clustering to a fixed level for all the different seasons. The data of March 1985 were clustered into four distinct station groups (Fig. 2a) at a similarity level of $50 \%$. Cluster 1 was confined to 18 oceanic stations. The transitional cluster 2 was roughly located along the continental shelf break and on the South Shetland Island shelf (Fig. 2b). The neritic cluster 3 contained 32 stations and covered large parts of the broad south-western shelf and most of the Bransfied Strait area. Cluster 4 consisted of only one single haul in the mesopelagic layer between 295 and $500 \mathrm{~m}$ of the neritic Gerlache Strait trench. Three other hauls between 200 and $450 \mathrm{~m}$, however, fitted well into the neritic cluster 3 .

For the dendrogram produced from the winter survey data we suggest a separation of clusters at the $67 \%$ similarity level (Fig. 3). The first group comprised of 20 stations in oceanic waters (Fig. 3b). 45 stations were grouped on the outer Peninsula shelf as a transitional zone, whereas 19 stations of the south-western shelf and in the Bransfield Strait were grouped as the neritic cluster 3. These neritic stations were carried out within the winter 

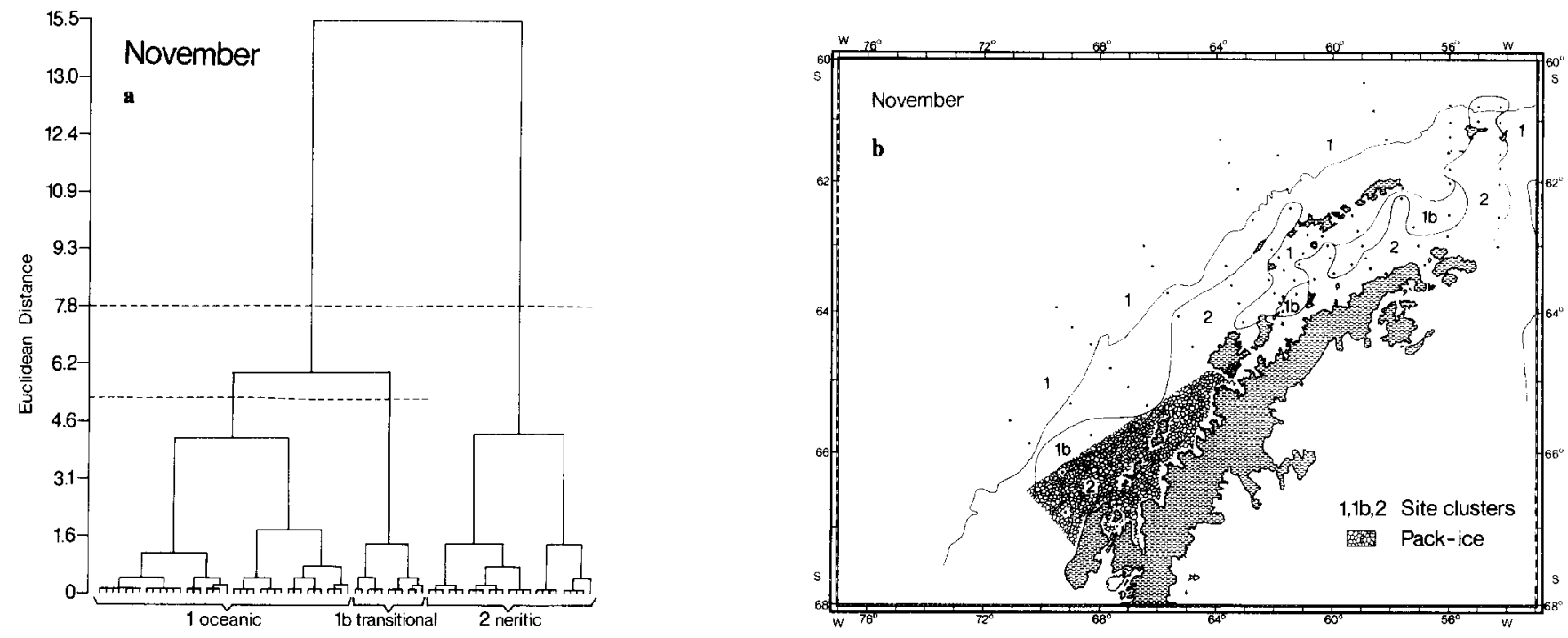

Fig. 4. a Dendrogram for site clusters from species abundance data of November 1987. b Geographical distribution of site clusters in November 1987

pack-ice zone. A further group of six hauls was rather heterogeneous, representing stations in the Bransfield and Gerlache Straits all beneath $200 \mathrm{~m}$ depth.

The plotted dendrogram of the spring survey of November 1987 indicated a meaningful similarity level at $50 \%$, resulting in two different clusters (Fig. 4a). Cluster 1 covered the oceanic zone, while cluster 2 represented stations in the neritic area (Fig. 4b). Cluster 1 can be further divided into two sub-groupings, separating a transitional cluster $1 \mathrm{~b}$ from the oceanic one. Despite the obvious similarity of cluster 1 and $1 \mathrm{~b}$ this separation seems to be meaningful as can be seen from the later dominance and constancy tables. These show, that $E u$ phausia crystallorophias is penetrating in large numbers into the transitional part (1b) of the otherwise oceanic cluster 1 . Establishing a transitional zone allows a much clearer distinction of the oceanic from the neritic site grouping. Since only epipelagic hauls down to $200 \mathrm{~m}$ were carried out during the spring survey, no mesopelagic cluster was expected from the data.

\section{Dominance and Constancy}

Results from computation of dominance and constancy of species reflect their presence and abundance in the survey area. It can then be tested to determine if these most common and abundant species are also valid as indicator

Table 1. Dominance of species (\%) calculated for different site clusters. Only those species are listed

\begin{tabular}{|c|c|c|c|c|c|c|}
\hline & Cluster & 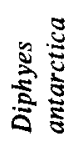 & 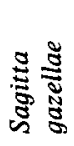 & 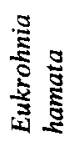 & 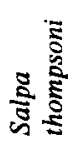 & 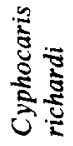 \\
\hline February 1982 & $\begin{array}{l}4 \text { oceanic } \\
1 \text { transitional } \\
2 \text { neritic } \\
3 \text { mesopelagic }\end{array}$ & $\begin{array}{r}- \\
\overline{6.7} \\
10.3\end{array}$ & $\frac{-}{-}$ & $\frac{1.0}{-}$ & $\begin{array}{l}3.9 \\
3.1 \\
\frac{7}{7.6}\end{array}$ & $\begin{array}{l}- \\
- \\
-\end{array}$ \\
\hline March 1985 & $\begin{array}{l}1 \text { oceanic } \\
2 \text { transitional } \\
3 \text { neritic }\end{array}$ & $\begin{array}{l}- \\
-\end{array}$ & $\begin{array}{l}- \\
3.3 \\
-\end{array}$ & $\begin{array}{r}1.0 \\
12.8 \\
2.7\end{array}$ & $\begin{array}{r}90.2 \\
14.3 \\
4.0\end{array}$ & - \\
\hline May/June 1986 & $\begin{array}{l}1 \text { oceanic } \\
2 \text { transitional } \\
3 \text { netitic } \\
4 \text { mesopelagic }\end{array}$ & $\begin{array}{l}- \\
- \\
-\end{array}$ & $\frac{-}{-}$ & $\begin{array}{l}2.9 \\
1.9 \\
2.7 \\
5.7\end{array}$ & $\begin{array}{r}43.0 \\
62.5 \\
6.8 \\
18.0\end{array}$ & $\frac{-}{-}$ \\
\hline November 1987 & $\begin{array}{l}1 \text { oceanic } \\
\text { lb transitional } \\
2 \text { neritic }\end{array}$ & $\begin{array}{l}4.8 \\
1.9 \\
-\end{array}$ & $\begin{array}{l}4.9 \\
1.0 \\
-\end{array}$ & $\begin{array}{l}9.7 \\
1.5 \\
-\end{array}$ & $\begin{array}{l}7.3 \\
-\end{array}$ & $\begin{array}{l}- \\
- \\
-\end{array}$ \\
\hline
\end{tabular}


species for different communities revealed from the classification. Dominance and constancy in terms of number are compiled in Tables 1 and 2.

Many species not found in the dominance table regularly occur in low absolute frequency thus having high values of constancy, e.g. the gastropod Clione limacina, the hyperiid amphipods Hyperiella dilatata and Primno macropa and the hydromedusa Calycopsis borchgrevinki. In February 1982 the krill Euphausia superba was the most abundant species and dominated the oceanic, transitional and neritic sites by $47.5 \%$ to $88.6 \%$ of total amount of individuals and constancy was high as $98.5 \%$ of the stations in the transitional cluster. Even in the mesopelagic station group deeper than $200 \mathrm{~m}$ krill was rank 3 of the dominant species following Eukrohnia hamata and Thysanoessa macrura. It has to be realized, however, that the deep hauls of February 1982 did not exceed a maximum depth of $400 \mathrm{~m}$, which might still be under strong influence of the mesopelagic zone.

In March 1985 salps were the dominant species in oceanic waters $(90.2 \%)$ with a constancy of $100 \%$. Krill did not play an important role in the oceanic and transitional sites. Even in the neritic zone krill did not exceed a dominance of $17.8 \%$. Thysanoessa macrura was the dominant species of the transitional and neritic sites during autumn. Species like Themisto gaudichaudii and Thysanoessa macrura had a higher constancy value in all areas than krill, indicating a more random distribution. No constancy values can be given for the mesopelagic cluster, because it consisted of a single station. It has to be remembered that this deep haul was carried out in the neritic zone of the Gerlache Strait, this expalins why the dominant species in this haul being Euphausia crystallorophias $(28.1 \%)$.

During the winter survey of May 1986 Salpa thompsoni dominated the oceanic and transitional cluster and ranked second in the mesopelagic zone of the Bransfield and Gerlache Straits, where Thysanoessa macrura was most abundant. The neritic surface waters were dominated by krill in winter, but compared to other seaons the dominance of Euphausia superba was relatively low (37.5\%), while the constancy was $90 \%$.

In spring of November 1987 Thysanoessa macrura and Euphausia superba were found to be the dominant components of the zooplankton in the oceanic cluster. Salps, the siphonophore Diphyes antarctica and chaetognaths were also regularly caught but in lower numbers. The transitional site group was dominated by Euphausia crystallorophias $(53.2 \%)$, which was the reason for the separation of this cluster from the oceanic cluster (Fig. 4). At the neritic stations Euphausia superba was the dominant species $(97.1 \%)$, as observed during the winter.

\section{Diversity and Evenness}

Species diversity stated as the Shannon-Wiener index $\left(\mathrm{H}^{\prime}\right)$ and evenness $(J)$ were calculated for each station. The median values as well as the confidence intervals of the indices for each site cluster are listed in Table 3.

The median values were rather low due to the occurrence of a few dominant species (e.g. Euphausia superba, Salpa thompsoni or Thysanoessa macrura). During all periods under consideration both diversity and evenness varied widely in each cluster. Few significant differences were detected between sites (U-test of Mann and Whitney, $P=0.05$ ).

In February 1982 diversity and evenness were significantly higher in the mesopelagic cluster than in the transitional and neritic station group, where krill was most abundant. In March 1985 the zooplankton of the transitional site was much more diverse than in the oceanic

\begin{tabular}{|c|c|c|c|c|c|c|c|c|c|}
\hline 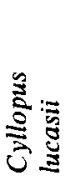 & 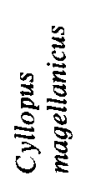 & 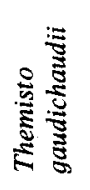 & 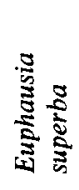 & 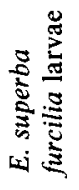 & 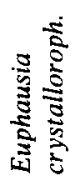 & 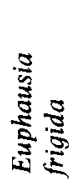 & 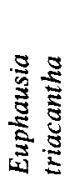 & 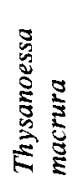 & 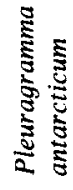 \\
\hline- & - & - & 88.6 & - & - & - & - & 5.7 & - \\
\hline- & - & 2.4 & 82.7 & - & - & - & $\ldots$ & 9.3 & - \\
\hline- & - & - & 47.5 & - & 32.5 & - & - & 12.0 & - \\
\hline- & - & 1.8 & 17.2 & - & - & 1.7 & - & 29.1 & - \\
\hline- & 1.3 & 1.7 & - & 1.5 & - & - & - & 1.4 & - \\
\hline- & - & 6.6 & 1.2 & - & - & 6.0 & -- & 52.8 & - \\
\hline- & - & 12.8 & 17.8 & 11.2 & 1.6 & 1.4 & - & 47.6 & - \\
\hline- & - & 2.4 & - & 13.0 & - & 16.4 & 12.4 & 5.1 & - \\
\hline- & - & 2.0 & - & 12.9 & - & 6.7 & - & 11.3 & - \\
\hline- & - & 2.4 & 37.5 & 11.2 & 4.0 & 6.7 & - & 19.5 & 4.7 \\
\hline 1.7 & - & 1.8 & 9.6 & - & 1.0 & - & - & 50.7 & 4.3 \\
\hline- & - & - & 15.2 & - & 1.1 & - & 1.8 & 44.7 & - \\
\hline- & - & - & 21.9 & - & 53.2 & - & - & 10.6 & 5.5 \\
\hline - & - & - & 97.1 & - & 1.0 & - & - & 1.4 & - \\
\hline
\end{tabular}


Table 2. Constancy of species $(\%)$ in different cluster sites. Only those species are listed occurring at least in one cluster with a

\begin{tabular}{|c|c|c|c|c|c|c|c|c|c|}
\hline & Cluster & 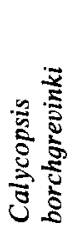 & 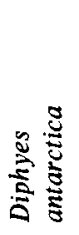 & 宽 & 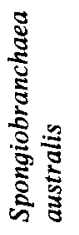 & 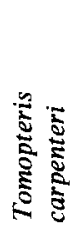 & 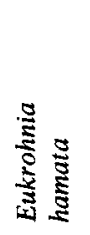 & 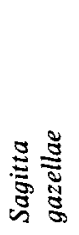 & 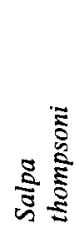 \\
\hline February 1982 & $\begin{array}{l}4 \text { oceanic } \\
1 \text { transitional } \\
2 \text { neritic } \\
3 \text { mesopelagic }\end{array}$ & $\begin{array}{l}28.6 \\
\overline{10.0} \\
40.0\end{array}$ & $\begin{array}{l}71.4 \\
43.6 \\
90.0 \\
95.0\end{array}$ & $\begin{array}{l}57.1 \\
11.3 \\
40.0 \\
75.0\end{array}$ & $\begin{array}{l}85.7 \\
20.0 \\
45.0\end{array}$ & $\begin{array}{l}71.4 \\
20.3 \\
35.0 \\
90.0\end{array}$ & $\begin{array}{r}98.0 \\
50.4 \\
89.0 \\
100.0\end{array}$ & $\begin{array}{l}96.5 \\
33.3 \\
80.1 \\
91.3\end{array}$ & $\begin{array}{r}100.0 \\
53.5 \\
15.0 \\
95.0\end{array}$ \\
\hline March 1985 & $\begin{array}{l}1 \text { oceanic } \\
2 \text { transitional } \\
3 \text { neritic }\end{array}$ & $\begin{array}{l}44.0 \\
39.0 \\
22.0\end{array}$ & $\begin{array}{l}39.0 \\
46.0 \\
22.0\end{array}$ & $\begin{array}{l}56.0 \\
41.0 \\
28.0\end{array}$ & $\begin{array}{l}83.0 \\
71.0 \\
46.0\end{array}$ & $\begin{array}{l}72.0 \\
57.0 \\
43.0\end{array}$ & $\begin{array}{l}56.0 \\
91.0 \\
94.0\end{array}$ & $\begin{array}{l}48.0 \\
77.0 \\
80.0\end{array}$ & $\begin{array}{r}100.0 \\
89.0 \\
68.0\end{array}$ \\
\hline May/June 1986 & $\begin{array}{l}1 \text { oceanic } \\
2 \text { transitional } \\
3 \text { neritic }\end{array}$ & $\begin{array}{l}80.0 \\
37.0 \\
10.0\end{array}$ & $\begin{array}{l}74.0 \\
38.0 \\
32.0\end{array}$ & $\begin{array}{l}67.0 \\
20.0 \\
38.0\end{array}$ & $\begin{array}{l}80.0 \\
22.0 \\
36.0\end{array}$ & $\begin{array}{l}74.0 \\
22.0 \\
16.0\end{array}$ & $\begin{array}{l}85.0 \\
93.0 \\
74.0\end{array}$ & $\begin{array}{l}71.0 \\
75.0 \\
69.0\end{array}$ & $\begin{array}{r}100.0 \\
100.0 \\
74.0\end{array}$ \\
\hline November 1987 & $\begin{array}{l}1 \text { oceanic } \\
1 \text { b transitional } \\
2 \text { neritic }\end{array}$ & $\begin{array}{l}50.0 \\
36.0 \\
16.0\end{array}$ & $\begin{array}{l}87.0 \\
73.0 \\
72.0\end{array}$ & $\begin{array}{l}53.0 \\
55.0 \\
40.0\end{array}$ & $\begin{array}{l}83.0 \\
46.0 \\
48.0\end{array}$ & $\begin{array}{l}45.0 \\
27.0 \\
-\end{array}$ & $\begin{array}{r}100.0 \\
91.0 \\
88.0\end{array}$ & $\begin{array}{l}93.0 \\
90.0 \\
76.0\end{array}$ & $\begin{array}{l}61.0 \\
55.0 \\
60.0\end{array}$ \\
\hline
\end{tabular}

Table 3. a Species diversity $\left(\mathbf{H}^{\prime}\right)$ and $\mathbf{b}$ evenness $(\mathrm{J})$ given as median and confidence limits for the different cluster sites and seasons

\begin{tabular}{lllll}
\hline Cluster & Month & & & \\
\cline { 2 - 4 } & February & March & May/June & November \\
\hline a & & & & \\
Oceanic & 1.419 & 1.158 & 1.385 & 1.504 \\
& $0.423-1.809$ & $0.744-1.360$ & $0.965-1.736$ & $1.277-1.835$ \\
Transitional & 0.898 & 1.374 & 1.375 & 1.281 \\
Neritic & $0.803-0.982$ & $1.158-1.651$ & $1.120-1.605$ & $0.931-1.513$ \\
Mesopelagic & 1.009 & 0.751 & 1.649 & 0.350 \\
& $0.487-1.680$ & $0.562-0.957$ & $1.245-1.852$ & $0.109-0.757$ \\
b & 1.671 & - & 1.412 & - \\
Oceanic & $1.332-1.934$ & - & $1.060-1.511$ & - \\
Transitional & & & & \\
& 0.537 & 0.499 & 0.531 & 0.637 \\
Neritic & $0.175-0.618$ & $0.356-0.588$ & $0.376-0.624$ & $0.508-0.742$ \\
Mesopelagic & 0.400 & 0.579 & 0.547 & 0.480 \\
& $0.351-0.446$ & $0.484-0.671$ & $0.462-0.616$ & $0.306-0.637$ \\
& 0.438 & 0.334 & 0.608 & 0.141 \\
& $0.180-0.637$ & $0.206-0.370$ & $0.436-0.691$ & $0.100-0.327$ \\
& $0.490-0.621$ & - & 0.456 & - \\
\hline
\end{tabular}

region, where the mass occurrence of salps greatly reduced the diversity index. In winter 1986 diversity was relatively high everywhere compared to the other seasons and the index of evenness was rather stable. This effect was due to the overall low abundance of the otherwise dominant species mentioned above. In spring 1987 diversity was significantly higher in the oceanic cluster than in the transitional site group, again affected by the very high dominance of Euphausia superba on the shelf.

The shift from low diversity in shelf waters and higher values in the open ocean during autumn to higher diversity in neritic areas during winter and back to the opposite situation again in spring indicate unpredictable changes in the indices. It is clear that these indices of constancy, evenness and dominance cannot give general definitions at site groupings which explain zooplankton community structure off the Antarctic Peninsula.

\section{Spearman's Rank Correlation of Species}

A Spearman's Rank Correlation test was applied to elucidate associations of species. Those taxa which occurred only once as a single specimen in each cluster site were 


\begin{tabular}{|c|c|c|c|c|c|c|c|c|c|c|c|}
\hline 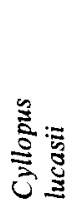 & 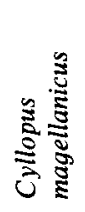 & 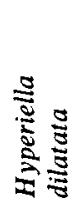 & 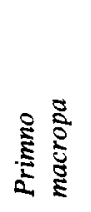 & 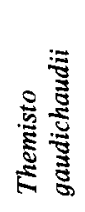 & 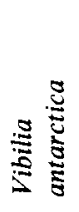 & 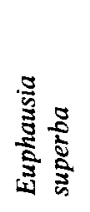 & 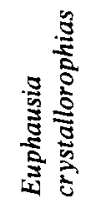 & 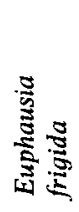 & 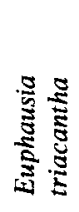 & 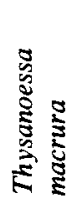 & 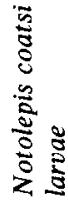 \\
\hline 42.9 & 14.3 & 85.7 & 85.7 & 100.0 & 57.1 & 57.1 & 28.6 & 14.3 & - & 100.0 & 42.9 \\
\hline 42.9 & - & 15.8 & 30.8 & 94.0 & 14.3 & 98.5 & 20.8 & 38.3 & 20.3 & 98.5 & 12.8 \\
\hline 10.0 & - & 20.0 & 20.0 & 55.0 & - & 85.0 & 50.0 & - & - & 90.0 & - \\
\hline 40.0 & - & 50.0 & 60.0 & 95.0 & 30.0 & 100.0 & 30.0 & 60.0 & 70.0 & 100.0 & 70.0 \\
\hline 55.0 & 89.0 & 22.0 & 50.0 & 89.0 & 72.0 & 38.0 & - & 27.0 & - & 89.0 & - \\
\hline 41.0 & 50.0 & 11.0 & 33.0 & 100.0 & 17.0 & 78.0 & - & 61.0 & 24.0 & 100.0 & 13.0 \\
\hline 31.0 & 13.0 & 15.0 & 18.0 & 97.0 & 12.0 & 97.0 & 16.0 & 61.0 & 18.0 & 100.0 & - \\
\hline 55.0 & 70.0 & 10.0 & 30.0 & 100.0 & 95.0 & 35.0 & - & 90.0 & 80.0 & 95.0 & 45.0 \\
\hline 91.0 & 73.0 & 24.0 & 24.0 & 96.0 & 73.0 & 51.0 & - & 82.0 & 44.0 & 100.0 & 18.0 \\
\hline 84.0 & 58.0 & 42.0 & 16.0 & 74.0 & 58.0 & 90.0 & 48.0 & 53.0 & 31.0 & 100.0 & 21.0 \\
\hline 55.0 & 21.0 & 58.0 & 42.0 & 24.0 & 13.0 & 95.0 & 15.0 & - & 24.0 & 92.0 & 16.0 \\
\hline 45.0 & - & 45.0 & 18.0 & 36.0 & - & 100.0 & 100.0 & - & 27.0 & 82.0 & - \\
\hline 72.0 & - & 64.0 & 36.0 & - & - & 100.0 & 44.0 & - & - & 88.0 & - \\
\hline
\end{tabular}

deleted from the computation. This reduced not only computer storage and time but also minimized biased correlations especially in small site groups, because a single recording gives $50 \%$ constancy in a site cluster of two stations and as such may mean very little (Stephenson et al. 1972).

Correlation matrices of species for each season were computed (Tables 4,5 ). The tables include only taxa that were significantly $(P=0.005)$ correlated to others. In the next stage of the analysis species groups were identified from the correlation matrix.

For each season this procedure led to a grouping of species which were positively correlated to each other and often negatively correlated to species of another group. In general the species groups could be easily superimposed to the geographical site clusters. For example, in May/June 1986 the species association around Euphausia cyrstallorophias was negatively correlated to Salpa thompsoni and Euphausia triacantha, while salps were negatively correlated to Euphausia crystallorophias, E. superba and Pleuragramma antarcticum larvae. These groups could be easily appointed to the neritic and oceanic site clusters.

Some species, however, showed positive correlations to species of various site groups. For example in March 1985 Eusirus microps and E. propeperdentatus were positively connected with the mesopelagic group around Antarctomysis ohlini but at the same time with the neritic group around Euphausia crystallorophia. In these unclear situations we excluded uncertain species like Eusirus spp. from the list of correlated species summarized in Table 6 .

The species of this revised table we can, in a very general sense, be called indicator species of the different geographical zooplankton zones during the different seasons. The species groups are defined as communities or associations (Mills 1969). In February 1982 the first species group consisted mainly of the larval stages of fish species (Table 6). This species association can be related to the neritic station group. The second species group was dominated by Salpa thompsoni, Euphausia frigida, Eupausia triacantha and hyperiid amphipods. No clear relationship to a single site cluster was evident, many of the taxa had relatively high constancy rates in the oceanic as well as in the mesopelagic station group. As can be seen from later results these species are primarily oceanic taxa. A distinct mesopelagic community was missing, probably because net hauls were not deep enough. A third group consisted of only Thysanoessa macrura and Themisto gaudichaudii, both species were very common and abundant in the entire survey area and not related to any specific site. There was obviously no species grouping derived from the correlation matrix, which would allow us to establish a distinct association for the transitional zone.

For March 1985 three species groupings could be separated following the results of the correlation analysis. Few species were correlated with salps (Table 6), and this group characterized primarily the oceanic station cluster. Another group negatively correlated to the first one included Euphausia crystallorophias and E. superba as the major components of the neritic community. A third group in which the amphipods Cyphocaris richardi, Scina sp. and the mysids Antarctomysis ohlini and Dactylamblyops hodgsoni were key species was relatively homogeneous and can be defined as mesopelagic.

For the winter cruise data of May 1986 again three species groupings were derived from rank correlation matrix analysis. The first group was similar in species composition to the neritic association of autumn 1985, e.g. Euphausia crystallorophias, Euphausia superba, Pleuragramma antarcticum larvae. The second group again showed great similarity to the species composition of the 
Table 4. Results from rank correlation analysis (Spearman correlation coefficient), for February 1982 and March 1985. Only those species are

\begin{tabular}{|c|c|c|c|c|c|c|c|c|c|c|c|c|c|c|c|c|}
\hline & February 1982 & & & & & & & & & & & & & & & \\
\hline & March 1985 & 1 & 2 & 3 & 4 & 5 & 6 & 7 & 8 & 9 & 10 & 11 & 12 & 13 & 14 & 15 \\
\hline 1 & Antarctomysis ohlini & & & & & & & & & & & & & & & \\
\hline 2 & Bathylagus antarcticus larvae & & & & & & & + & & & & & & & & \\
\hline 3 & Brachioteuthis picta & & & & + & & & & & & & & & & & \\
\hline 4 & Calycopsis borchgrevinki & & & & & & & + & & + & & & + & & & \\
\hline 5 & Chionodraco rastrospinosus larv. & & & & & & & & & & & & & & & \\
\hline 6 & Clio pyramidata & & & & & & & + & & & & & & + & & \\
\hline 7 & Clione limacina & & & + & & & & & & & & & + & + & & \\
\hline 8 & Cyllopus lucasii & & & & & & & & & & & & & & & \\
\hline 9 & Cyllopus magellanicus & & & & & & & + & & & & & & + & & \\
\hline 10 & Cyphocaris richardi & + & & & & & & & & & & & & & & \\
\hline 11 & Dactylamblyops hodgsoni & + & & & & & & & & & + & & & & & \\
\hline 12 & Diphyes antarctica & & & & & & & & & & & & & & & \\
\hline 13 & Electrona antarctica larvae & + & & & + & & & & & & + & + & & & & \\
\hline 14 & Euphausia crystallorophias & & & & & + & & & & & & & & & & \\
\hline 15 & Euphausia frigida & & & & & & & & & & & & & & & \\
\hline 16 & Euphausia superba & & & & & & & + & & - & & & & & + & \\
\hline 17 & Euphausia triacantha & & & & & & & & & & & & & & & \\
\hline 18 & Eusirus microps & + & & & & & & & & & + & + & & + & + & \\
\hline 19 & Eusirus propeperdentatus & + & & & & + & & & & & + & + & & & + & \\
\hline 20 & Galiteuthis glacialis & & & & & & & & & & & & & & & \\
\hline 21 & Hyperia antarctica & & & & & & & & & & & & & & & \\
\hline 22 & Hyperiella antarctica & & & & & & & & & & & & & & & \\
\hline 23 & Hyperiella dilatata & & & & & & & & & & & + & & & & \\
\hline 24 & Hyperoche medusarum & & & & & & & & & & & & & & & \\
\hline 25 & Limacina helicina & & & & & & & & & & & & & & & \\
\hline 26 & Notocrangon antarcticus larvae & & & & & & & & & & & & & & & \\
\hline 27 & Notolepis coatsi larvae & & & & & & & & & & & & & & & \\
\hline 28 & Notothenia kempi larvae & & & & & & & & & - & & & & & & \\
\hline 29 & Nototheniops larseni larvae & & & & & & & & & & & & & & & \\
\hline 30 & Nototheniops nudifrons larvae & & & & & & & & & - & & & & & + & \\
\hline 31 & Orchomene plebs & & & & & & & & & & & & & & + & \\
\hline 32 & Orchomene rossi & + & & & & & & & & & & + & & & & \\
\hline 33 & Pleuragramma antarcticum larv. & + & & & & & & & & - & + & & & & + & \\
\hline 34 & Primno macropa & & & & & & & & & & & & & & & \\
\hline 35 & Salpa thompsoni & & & & & & & + & & + & & & & & - & \\
\hline 36 & Scina species & + & & & & & & & & & + & + & & + & & \\
\hline 37 & Spongiobranchaea australis & & & & & & & & & & & & & & & \\
\hline 38 & Themisto gaudichaudii & & & & & & & & & & & & & & & \\
\hline 39 & Thysanoessa macrura & & & - & & & & & & - & & & & & & + \\
\hline 40 & Tomopteris carpenteri & & & & & & & & & & & & & & & \\
\hline 41 & Travisiopsis levinseni & & & & & & & & & & & & & & & \\
\hline 42 & Vanadis antarctica & & & & & & & & & & & & & & & \\
\hline 43 & Vibilia antarctica & & & & & & & & & + & & & & & & \\
\hline
\end{tabular}

mesopelagic cluster of March 1985, e.g. Cyphocaris richardi, Antarctomysis ohlini. Some other species were negatively correlated to the members of the neritic and mesopelagic group, e.g. salps, Euphausia triacantha and Euphausia frigida. Salps and krill furcilia larvae were abundant in oceanic waters, and with other species like Euphausia triacantha, Euphausia frigida, Tomopteris spp. polychaetes and cephalopods they characterized the oceanic region. Once again no distinct species grouping was found which could be defined as a transitional community.

Two clearly separated species groups were found for the November 1987 zooplankton data. Since salps occurred more rarely in this season, they were missing in the list of oceanic indicator species. As in all other seasons the gastropod Clione limacina was found in the oceanic community (Table 6). Euphausia triacantha, the siphonophore
Diphyes antarctica and the polychaet Vanadis antarctica were also common members of the oceanic association. The number of neritic indicator species was relatively high in spring, because of the large number of larval fish species (Table 6). Some species are given in brackets in Table 6, because they occurred as indicator species of different communities during different seasons. Since no obvious reason can be given why e.g. Hyperiella dilatata switches from the neritic community in spring to the oceanic in summer and to the mesopelagic in winter, these species are poor indicator species.

\section{Conclusions and Discussion}

Application of the cluster analysis has given as a first result a dendrogram which divided the hauls into a maximum of 4 site groups. Dendrograms have the advantage of sim- 


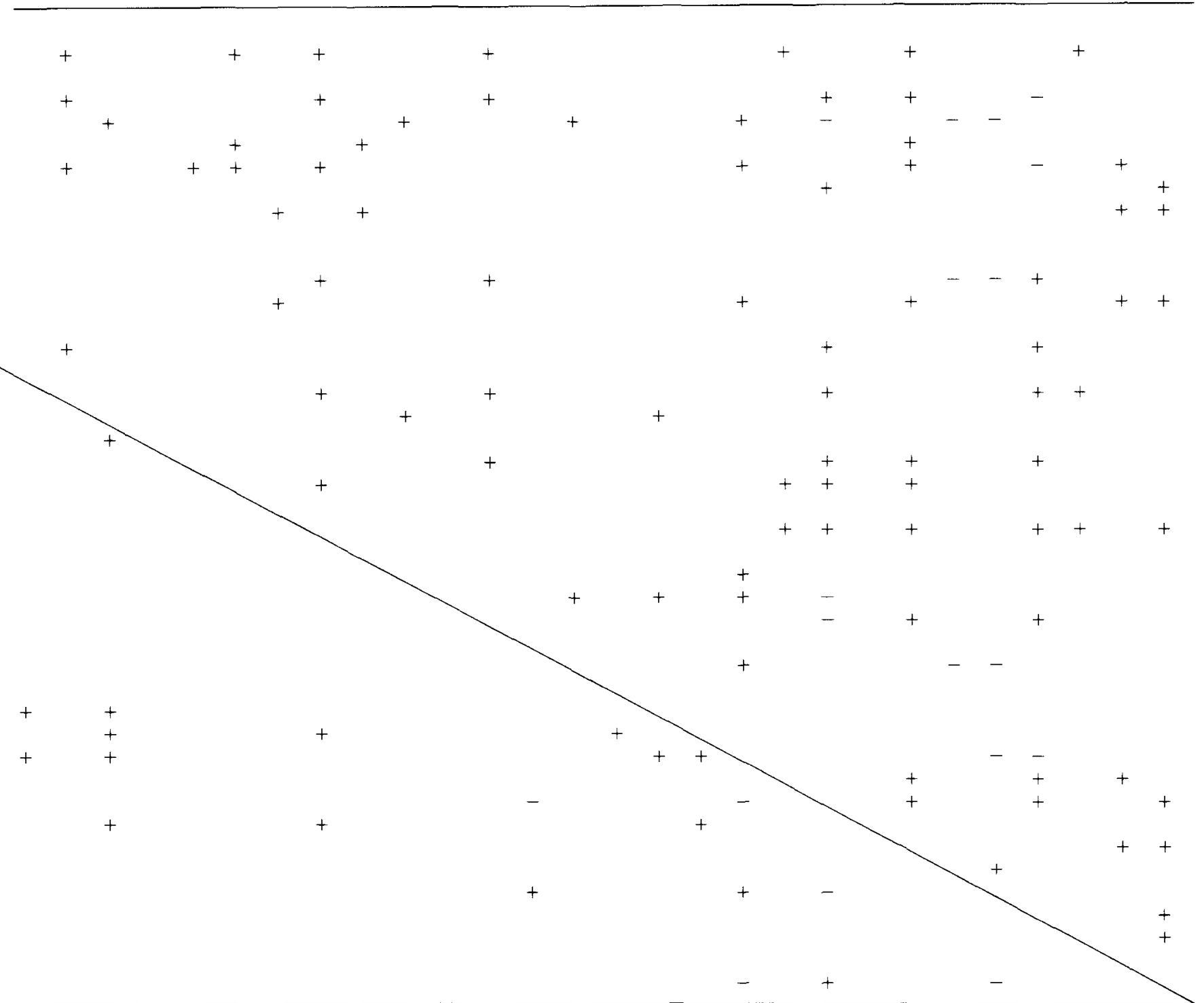

plicity and distinctness, however the levels of similarity are arbitrary and data may be forced into classes, because dendrograms tend to overemphasize discontinuities, although continua may exist (Field et al. 1982).

The results of calculating species dominance and constancy as well as diversity indices indicated that many species occur in more than one site cluster. No species could be called a perfect indicator species in a very strict sense, as they all occurred in more than one site group. This led us to the conclusion that a simple designation of communities in terms of dominance and constancy of species is not possible for the area investigated. Regarding these problems we thought it advisable to apply a somewhat more independent method to present species relationships before superimposing species groups to site clusters. By this procedure we in advance excluded all species uncorrelated to any community.
Despite the fact that single species could not be attributed perfectly to discrete site clusters, the calculation of a species rank correlation matrix for each season revealed groups which could be correlated to site clusters, i.e. a group of several co-occurring 'imperfect' indicator species is interpretable as a community of a defined geographical zone.

Indicator species and communities have often been used in marine zooplankton biology as characteristics in the description of different water masses. For the Antarctic Peninsula area this has been attempted by Piatkowski (1989). Various types of water masses of different origin are reported in the literature for this area. Bellingshausen Sea water, Weddell Sea Water, local Bransfield Strait water and various types of mixing were described (BIOMASS 1982; Sievers 1982; Heywood 1985). Only two epipelagic plankton communities face a maximum of ten 
Table 5. Results from rank correlation analysis (Spearman correlation coefficient) for May/June 1986 and November 1987. Only those species

\begin{tabular}{|c|c|c|c|c|c|c|c|c|c|c|c|c|c|c|c|c|c|c|c|c|c|}
\hline & $\frac{\text { May/June } 1986}{\text { November } 1987}$ & 1 & 2 & 3 & 4 & 5 & 6 & 7 & 8 & 9 & 10 & 11 & 12 & 13 & 14 & 15 & 16 & 17 & 18 & 19 & 20 \\
\hline 1 & Antarctomysis ohlini & & & & & & & & & & & & & & + & & & & & & \\
\hline 2 & Bathylagus antarcticus lar. & & & & & & & & & & & & & & & & & & & & \\
\hline 3 & Beroe cucumis & & & & & & & & & & & & & & & & & & & & \\
\hline 4 & Beroe forskalii & & & & & & & & & & & & & & & & & & & & \\
\hline 5 & Brachioteuthis picta & & & & & & + & & & & & & & & & & & & & + & \\
\hline 6 & Calycopsis borchgrevinki & & & & & & & & & & & & & & & & + & & - & & - \\
\hline 7 & Chaenocephalus aceratus la. & & & & + & & & & & & & & & & & & & & & & \\
\hline 8 & Chionodraco rastrosp. larv. & & & & & & & & & & & & & & & & & & & & \\
\hline 9 & Clio pyramidata & & & & & & & & & & & & & & & & & & & & \\
\hline 10 & Clione limacina & & & & & & & & & & & & - & & & & & & & & \\
\hline 11 & Cryodraco antarcticus larv. & & & & & & & & & & & & & & & & & & & & \\
\hline 12 & Cyllopus lucasii & & & & & & & & & & & & & & & & & & & & \\
\hline 13 & Cyllopus magellanicus & & & & & & & & + & & & & & & & & & & & - & \\
\hline 14 & Cyphocaris richardi & & & & & & & & & & & & & & & & & & & & \\
\hline 15 & Desmonema gaudichaudi & & & & & & & & & & & & & & & & & & & & \\
\hline 16 & Diphyes antarctica & & & & & & + & & & & & & & & & & & & & & \\
\hline 17 & Eukrohnia hamata & & & & & & + & & & & + & & & & & & + & & & & \\
\hline 18 & Euphausia crystallorophias & & & & & & & & & & & & & & & & & & & & + \\
\hline 19 & Euphausia frigida & & & & & & & & & & & & & & & & & & & & \\
\hline 20 & Euphausia superba & & & & & & & & & & & & & & & & & & & & \\
\hline 21 & Euphausia superba larvae & & & & & & & & & & & & & & & & & & & & \\
\hline 22 & Euphausia triacantha & & + & & & & & & & & & & & & & & & + & & & \\
\hline 23 & Eusirus antarcticus & & & & & & + & & & & & & & & & & & & + & & \\
\hline 24 & Eusirus microps & & & & & & & & & & & & & & & & & & & & \\
\hline 25 & Eusirus propeperdentatus & & & & + & & + & & & & & & & & & & + & & & & \\
\hline 26 & Galiteuthis glacialis & & & & & & & & & & & & & & & & & & & & \\
\hline 27 & Harpagifer antarcticus lar. & & & & & & & & & & & & & & & & & & & & \\
\hline 28 & Hyperia macrocephala & & & & + & & & & & & & & & & & & & & & & \\
\hline 29 & Hyperiella dilatata & & & & & & & & + & & & & & & & & & & & & \\
\hline 30 & Hyperoche medusarum & & & & & & & & & & & & & & & & & & & & \\
\hline 31 & Limacina helicina & & & & & & & & & & & & & & & & & & & & \\
\hline 32 & Notocrangon antarcticus la. & & & & & & & & & & & & & & & & & & & & \\
\hline 33 & Notolepis coatsi larvae & & & & & & & & & & & & & & & & & & & & \\
\hline 34 & Notothenia kempi larvae & & & & & & & & & & & & & & & & & & & & \\
\hline 35 & Nototheniops larseni larv & & & & & & & & & & & & & & & & & & & & \\
\hline 36 & Nototheniops nudifrons lar. & & + & & & & & & & & & & & & & & & & & & \\
\hline 37 & Orchomene plebs & & & & & & & & & & & & & & & + & & & + & & \\
\hline 38 & Orchomene rossi & & & & & & & & & & & + & & & & & + & & & & \\
\hline 39 & Pagetopsis macropterus lar. & & & & & & & & & & & & & & & & & & & & \\
\hline 40 & Parachaenichthys charce. la. & & & & & & & + & & & & & & & & & + & & & & \\
\hline 41 & Pleuragramma antarctic. la. & & & & & & & + & & & & & & & & & & & + & & \\
\hline 42 & Salpa thompsoni & & & & & & & & & & & & & & & & & & & & \\
\hline 43 & Themisto gaudichaudii & & & & & & & & & & & & & & & & & & & & \\
\hline 44 & Thysanoessa macrura & & & & & & & & & & & & & & & & & & & & \\
\hline 45 & Tomopteris carpenteri & & & & & & & & & & & & & & & & & & & & \\
\hline 46 & Trematomus newnesi larvae & & & & & & & + & & & & & & & & & & & + & & \\
\hline 47 & Vanadis antarctica & & & & & & & & & & + & & & & & & & & & & \\
\hline 48 & Vibilia antarctica & & & & & & & & & + & & & & & & & & & & & \\
\hline
\end{tabular}

types of water masses. The water masses along the Peninsula are split to such a fine level that it is impossible to attribute the detected communities to distinct water masses.

We can only roughly appoint areas with plankton communities, e.g. an oceanic or probably West Wind Drift plankton association and a neritic or probably East Wind Drift community. The neritic community, for example, is under the influence of Weddell Sea water in the Bransfield Strait. Further to the south-west, south of the Palmer Archipelago, where the influence of the Weddell Sea disappears, the same community is living in the Bellingshausen Sea water mass. Even the large, unmixed water masses do not exhibit their own plankton community, but the determining factor for the composition of the zooplankton communities seems to be the proximity of the continental shelf. This is quite obvious from the indicator species of the neritic association, which consists to a high degree of bottom living decapod and fish species larvae.

From the comparison of site and species groups it was evident that especially the transitional cluster could not be attributed to any defined species group. The main dif- 


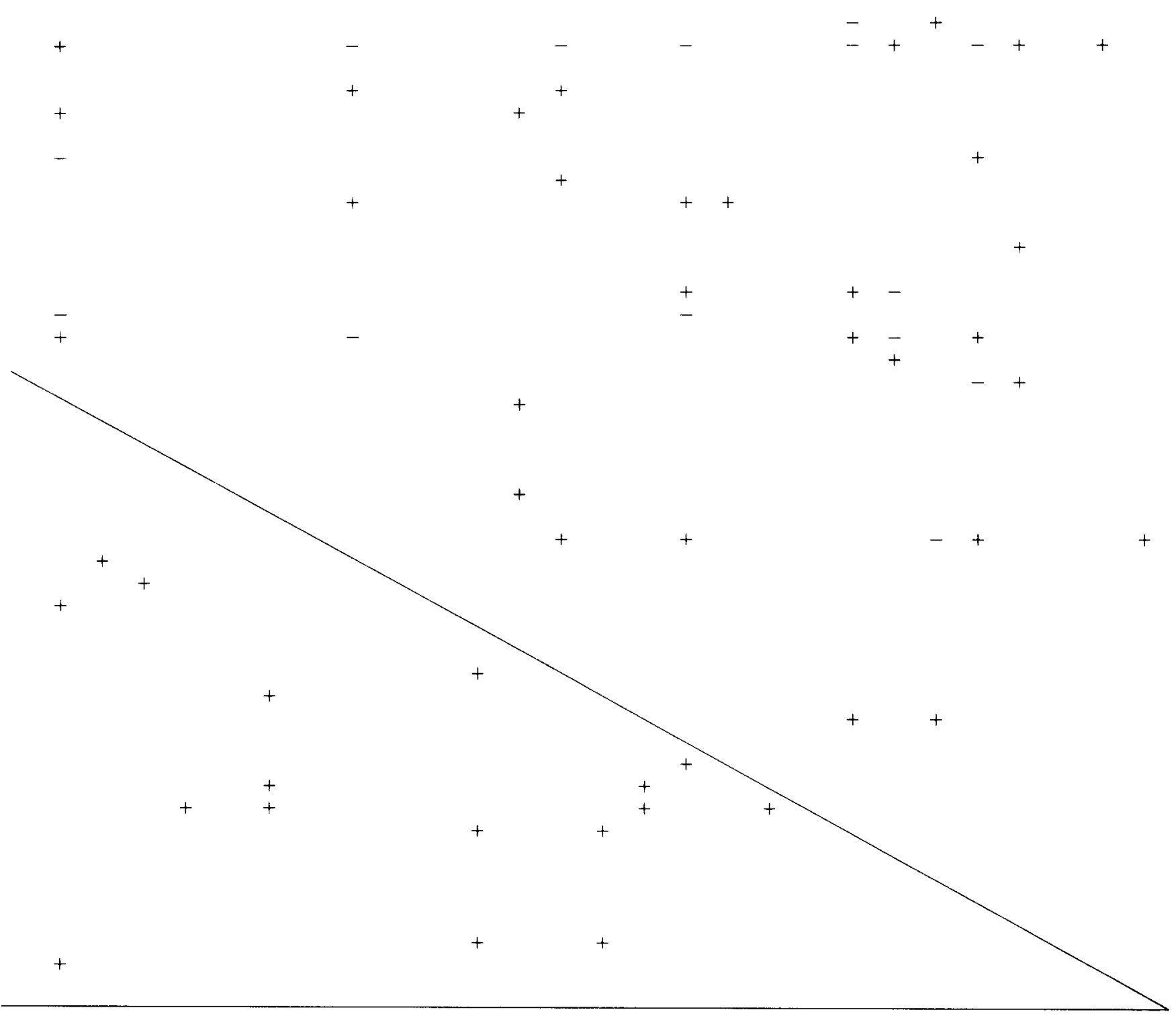

ferences between transitional and oceanic or neritic areas which led to the observed clusters of stations were due to changes in abundance rather than changes in the species composition. We therefore define the transitional site cluster as a transitional mixing zone and not as a community with own characteristics, because here mainly the characteristics of the oceanic and neritic communities are diminished.

There were no sharp geographical boundaries between the various communities, neither horizontally nor vertically. Hauls from 200 to $400 \mathrm{~m}$ depth sometimes belonged to epipelagic and sometimes to mesopelagic clusters. Species groupings from below $400 \mathrm{~m}$ deep always fell into the mesopelagic cluster. Possibly the 200 to $400 \mathrm{~m}$ depth layer is an overlapping/mixing zone. A further possible explanation might be a daily/seasonal vertical migration of species which would result in a diffuse layer between the epipelagic and mesopelagic communities (see also Ainley et al. 1986).

Some information on Antarctic zooplankton communities are available in the literature. RakusaSuszczewski (1983) described three associations off the 
Table 6. Indicator species of plankton communities off the Antarctic Peninsula for different seasons. ( $F=$ February 1982, $M=M a r c h ~ 1985, J$ = May/June 1986, $\mathbf{N}=$ November 1987). Species in brackets are doubtful for classification, explanation see text

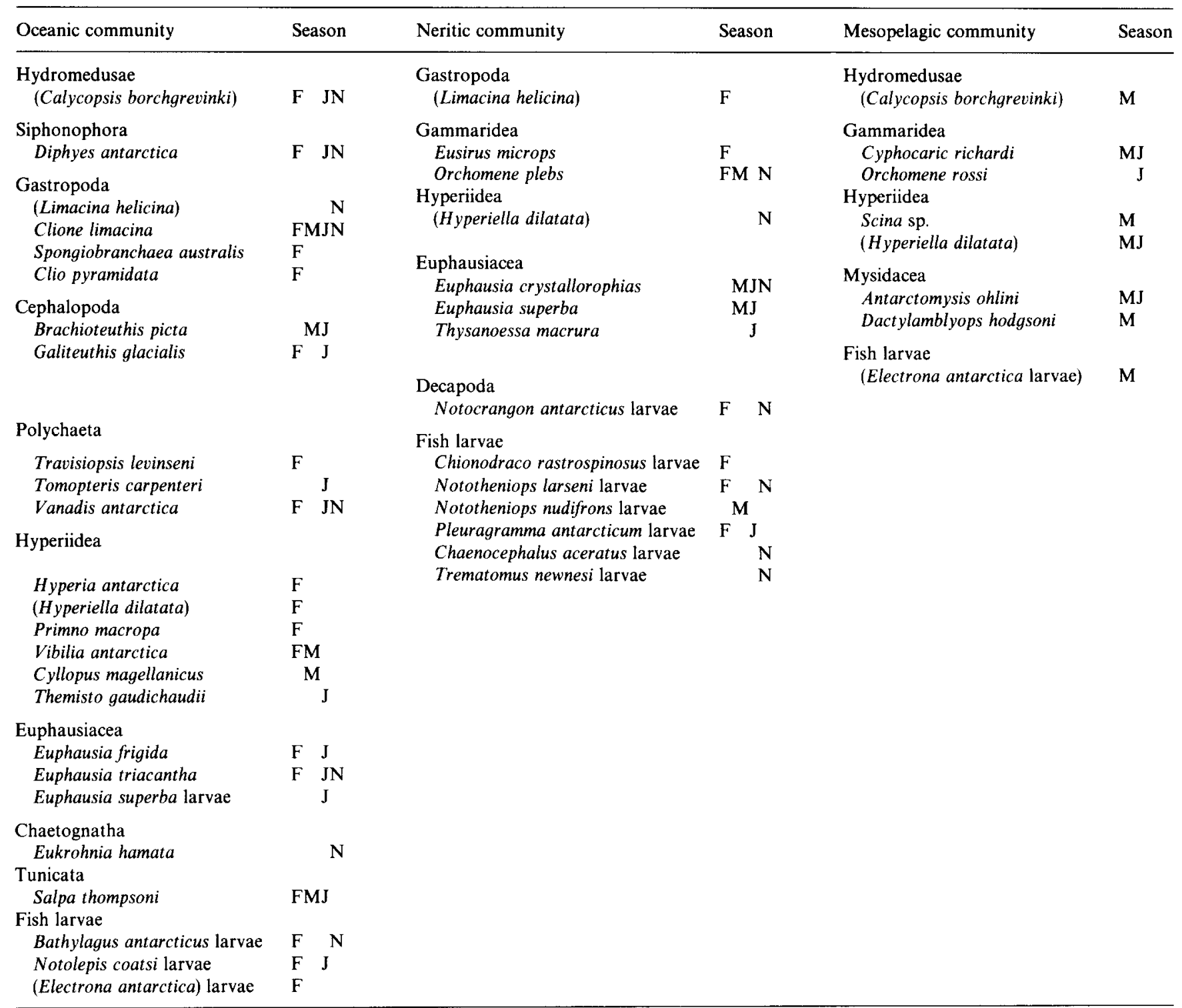

Antarctic Peninsula and mentioned several taxa to be important for these communities. Jazdzewski et al. (1982) emphasized some discrepancies between their analysis and the data published by Rakusa-Suszczewski (1983), because differences in interpretation resulted from the oversimplification of preliminary results. Rakusa-Suszczewski (1983) separated the communities by distinguishing plankton species in areas of different krill biomass. We do not believe this an adequate method, basing the description on one species without knowing its diagnostic value. Jazdzewski et al. (1982) compared sample volume and weight and the number of individuals per sample. High values were found in oceanic waters, which the authors call Antarctic, and low values in the shelf area which they define as continental. For these two groups of sampling sites they described dominant and subdominant species, mainly copepods. Our interpretation of diversity and evenness has shown that these parameters may change with time and that in general parameters like overall biomass or number of individuals cannot serve to define distinct community sites.

The diagnosis of multispecies data sets from plankton surveys usually results in complex patterns and relationships which need to be extracted. Results from more intuitive methods are often biased due to subjective interpretation of data by neglecting potentially important species or by oversimplification. The use of numerical techniques is a more objective approach to the classification of sites and species. Methods of multivariate data analysis have only recently been applied to describe Antarctic zooplankton communities. Boysen-Ennen and Piatkowski (1988) used cluster analysis on zooplankton data of the eastern Weddell Sea, describing three communities, a southern and a north-eastern shelf association 


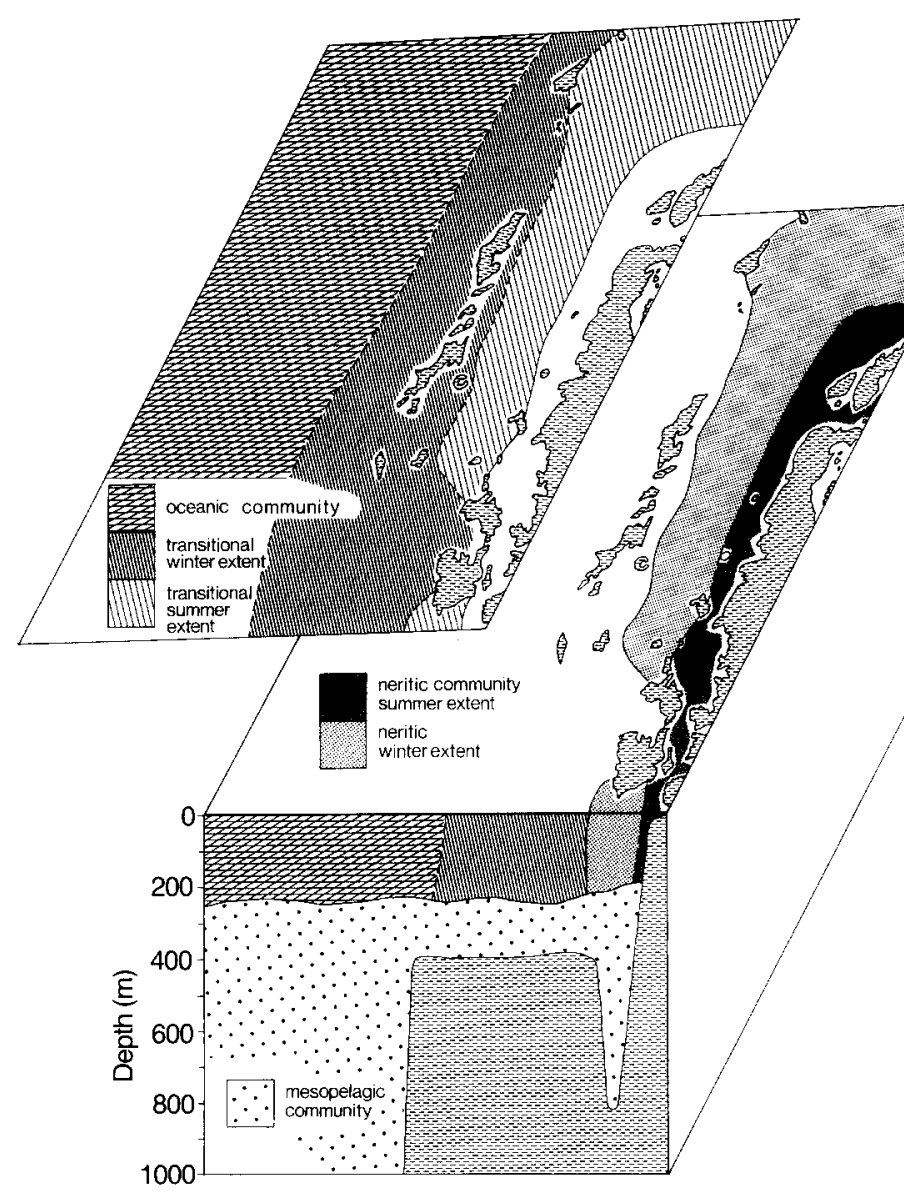

Fig. 5. Generalized picture for the seasonal distribution of the oceanic, neritic and mesopelagic zooplankton communities along the Antarctic Peninsula

and an oceanic community. Hubold et al. (1988) submitted data from the same area, but from two different seasons, to a cluster analysis and revealed marked similarities between the southern and northern shelf depending on the time of the year. This probably indicated the development of the zooplankton during the horizontal transport in the surface layer to the south.

The oceanic community Boysen-Ennen and Piatkowski (1988) worked out for the eastern Weddell Sea is very similar to the oceanic association Piatkowski (1989) found off the Antarctic Peninsula, i.e. a zooplankton group dominated by gelatinous species, mainly salps. In the Antarctic Peninsula region the author also distinguished a Bellingshausen water community, a transitional and a neritic community, but noted, that the separation of communities was much clearer in the Weddell Sea. We reanalysed these data with some modifications using the standardized individual numbers of each haul and not the integrated mean for grouped hauls from different depth layers. We also log-transformed the data to scale down the scores of abundant species. The results differ slightly from those obtained by Piatkowski (1989), because the site and species composition led us to the conclusion that besides a small neritic community the offshore shelf area is often strongly influenced by the oceanic community. It becomes a transitional mixing zone, which would include Piatkowski's (1989) Bellingshausen Water Community. The classification of Piatkowski (1989) has probably been taken to too fine a level, tending to overemphasize discontinuities and forcing a graded series into discrete groups as discussed by Field et al. (1982).

Problems of analysis and interpretation arise when variations of communities in terms of area and season are considered. As already mentioned Hubold et al. (1988) demonstrated that site groups alter their composition probably by advection of plankton from another site. This problem is increased if developmental stages of species are considered as taxa. This can inflate the number of associations and reduce the length of time they exist to particular times during the year. In our analysis there were few species whose numbers remained constant from one season to the next. Euphausia superba is one example demonstrating the variable relationship to an association. During autumn and winter krill were mainly concentrated in nearshore waters along the Antarctic Peninsula resulting in a significant correlation with Euphausia crystallorophias a constituent of the neritic community. In spring and summer krill were highly abundant in the entire area from neritic to oceanic waters, no correlation to other species occurred and no preference was observed to any community site. This pattern of krill occurrence was evident during earlier years and has been described in detail by Siegel $(1988,1989)$. Differences in species distribution patterns have also been reported for copepod species (Voronina 1972) and chaetognaths (David 1958), which perform seasonal vertical migrations between the surface and deeper mesopelagic layers.

The communities described above and generally displayed in Fig. 5 reflect a relatively homogeneous species composition with the location of the community sites relatively stable over several seasons: the oceanic association beyond the continental slope, the neritic one in nearshore waters of the Peninsula coast and the mesopelagic community primarily in water layers deeper than 
200 to $300 \mathrm{~m}$. Variability was observed in the abundance of individuals with time.

The present investigation considered the communities as a list of co-occurring species encountering space and time. No information can be gained if we are dealing with loosely integrated aggregations - where species simply cooccur independent or if we are examining a highly stable co-adapted group. Covering this question will require much more detailed work on environmental and biological species interactions.

Acknowledgements. The authors are very much indebted to all colleagues and members of the ships crews who helped to collect the large amount of plankton samples. We like to thank P. Rodhouse (BAS) and A. Kellermann (AWI) for the identification of cephalopods and fish larvae species, respectively. We are very much indebted to E. Murphy (BAS) for language editing. We are grateful to Miss U. Harm for her ardour of work and technical assistance. The first author was supported by fundings of the Federal Ministry of Research and Technology (MFE 0534.3).

\section{References}

Ainley DG, Fraser WR, Sullivan CW, Torres JJ, Hopkins TL, Smith WO (1986) Antarctic mesopelagic mikronekton: Evidence from seabirds that pack ice affects community structure. Science 232: 847-849

Anonymous (1986) Antarctic Expeditions of the Federal Republic of Germany with RV "Polarstern" (Legs II/2, 1983 and III/2, 1984) and FRV "Walther Herwig" in 1985. Arch Fischereiwiss 37 Beih 1:1-234

Baker A de C, Clatke MR, Harris MJ (1973) The N.I.O. combination net (RMT 1 +8) and further developments of Rectangular Midwater Trawls. J Mar Biol Assoc UK 53:167-184

BIOMASS (1982) First post-FIBEX hydrographic data interpretation workshop. BIOMASS Rep Ser 30:1-11

Boysen-Ennen E, Piatkowski U (1988) Meso- and macroplankton communities in the Weddell Sea. Polar Biol 9:17-35

David PM (1958) The distribution of the Chaetognatha of the Southern Ocean. Discovery Rep 29:200-229

Field JG, Clarke KR, Warwick RM (1982) A practical strategy for analysing multispecies distribution patterns. Mar Ecol Prog Ser $8: 37-52$

Foxton P (1966) The distribution and life history of Salpa thompsoni Foxton with observations on a related species Salpa gerlachei Foxton. Discovery Rep 34:1-116

Fütterer DK (1988) Die Expedition ANTARKTIS-VI mit FS "Polarstern" 1987/1988. Ber Polarforsch 58:1-267

Hardy AC, Gunther ER (1935) The plankton of the South Georgia whaling grounds and adjacent waters, 1926-1927. Discovery Rep $11: 1-456$

Hempel G (1985) On the biology of polar seas, particularly the Southern Ocean. In: Gray JS, Christiansen ME (eds) Marine biology of polar regions and effects of stress on marine organisms. Wiley \& Sons, New York, pp 3-34

Hempel G, Heywood RB (1982) Joint Biological Expedition on RRS "John Biscoe", February 1982. Ber Polarforsch 5:1-38

Heywood RB (1985) Environmental conditions in the Antarctic Peninsula area of the Southern Ocean during the Anglo-German Joint Biological Expedition, February 1982. Meeresforschung 30:220-239
Hopkins TL (1985) The zooplankton community of Croker Passage Antarctic Peninsula. Polar Biol 4:161-170

Hubold G, Hempel I, Meyer M (1988) Zooplankton communities in the southern Weddell Sea (Antarctica). Polar Biol 8:225-233

Jazdzewski K, Kittel W, Lotocki K (1982) Zooplankton studies in the southern Drake Passage and in the Bransfield Strait during the austral summer (BIOMASS-FIBEX, February-March 1981). Pol Polar Res 3 $(3 / 4): 203-242$

Kane JE (1966) The distribution of Parathemisto gaudichaudii (Guer.), with observations on its life history in the $0^{\circ}$ to $20^{\circ} \mathrm{E}$ sector of the Southern Ocean. Discovery Rep 34:163-198

Mackintosh NA (1934) Distribution of macroplankton in the Atlantic sector of the Antarctic. Discovery Rep 9:65-160

Marr JWS (1962) The natural history and geography of the Antarctic krill (Euphausia superba Dana). Discovery Rep 32:33 -464

Mills EL (1969) The community concept in marine zoology, with comments on continua and instability in some marine communities: A review. J Fish Res Board Can 26:1415-1428

Montu MA, Oliveira IR (1986) Zooplanktonic associations, trophic relations and standing stock of krill and other groups of the community near Elephant Island (February-March 1984-1985). Neritica $1: 111-130$

Nemoto T, Harrison G (1981) High latitude ecosystems. In: Longhurst AR (ed) Analysis of marine ecosystems. Academic Press, London New York, pp 95-126

Piatkowski U (1983) Joint Biological Expedition on RRS "John Biscoe", February 1982 (II). Data of micronekton and zooplankton hauls. Ber Polarforsch 11:1-40

Piatkowski U (1989) Macroplankton communities in Antarctic surface waters: spatial changes related to hydrography. Mar Ecol Prog Ser $55: 251-259$

Pommeranz T, Herrmann C, Kühn A (1982) Mouth angles of the Rectangular Midwater Trawl (RMT $1+8$ ) during paying out and hauling. Meeresforschung 29:267-274

Rakusa-Suszczewski S (1983) The relationship between the distribution of plankton biomass and plankton communities in the Drake Passage and the Bransfield Strait (BIOMASS-FIBEX, February-March 1981). Mem Natl Inst Polar Res Spec Issue 27:77-83

Roe HSJ, Shale DM (1979) A new multiple Rectangular Midwater Trawl (RMT $1+8)$ and some modifications to the Institute of Oceanographic Science's RMT 1+8. Mar Biol 50:283-288

Schnack-Schiel SR (1987) The Winter-Expedition of RV "Polarstern" to the Antarctic (ANT V/1-3). Ber Polarforsch 39:1-259

Siegel V (1988) A concept of seasonal variation of krill (Euphausia superba) distribution and abundance west of the Antarctic Peninsula. In: Sahrhage $D$ (ed) Antarctic Ocean and resources variability. Springer, Berlin Heidelberg New York, pp 219-230

Siegel V (1989) Winter and spring distribution and status of krill stock in Antarctic Peninsula waters. Arch Fischereiwiss 39:45-72

Sievers HA (1982) Description of the physical oceanographic conditions, in support of the study of the distribution and behaviour of krill. INACH Sci Ser 28:73-122

Snedecor GW, Cochran WG (1980) Statistical methods, 7th edn. Iowa State University Press, pp 507

Stephenson W, Williams WT, Cook SD (1972) Computer analyses of Petersen's original data on bottom communities. Ecol Monogr 42:387-408

Voronina NM (1972) Vertical structure of a pelagic community in Antaretica (in Russian). Okeanologiya 12:492-498

Witek Z, Kittel W, Czykieta H, Zmijewska MI, Presler E (1985) Macrozooplankton in the southern Drake Passage and in the Bransfield Strait during BIOMASS-SIBEX (December 1983-January 1984). Pol Polar Res 6:95-115 